Boletín de la Sociedad Geológica Mexicana

VOLUMEN 65, NÚM. 1, 2013, P. 39-50

\title{
Nitrate mass balance in agricultural areas of intensive fertilizer application: the North Maresme aquifer system case study (Spain)
}

\author{
Antonio Hernández-Espriú ${ }^{1, *}$, Eloisa Domínguez-Mariani², José Antonio Reyna-Gutiérrez ${ }^{3,1}$, \\ Pedro Martínez-Santos ${ }^{4}$, Emilio Sánchez-León ${ }^{5,1}$, Luis E. Marín ${ }^{6}$ \\ ${ }^{1}$ Hydrogeology Group, Earth Sciences Division, Faculty of Engineering, Universidad Nacional Autónoma de México (UNAM). \\ Ciudad Universitaria, México, D.F., Zip code 04360, México. \\ ${ }^{2}$ Centro Interamericano de Recursos del Agua (CIRA), Faculty of Engineering, Universidad Autónoma del Estado de México \\ (UAEM). \\ ${ }^{3}$ Department of Environmental Engineering, Danmarks Tekniske Universitet, Denmark. \\ ${ }^{4}$ Department of Geodynamics, Faculty of Geological Sciences, Universidad Complutense de Madrid. \\ ${ }^{5}$ Department of Geosciences, Ebehard Karls Universitat Tubingen, Tubingen, Germany. \\ ${ }^{6}$ Department of Natural Resources, Institute of Geophysics, Universidad Nacional Autónoma de México. \\ *ahespriu@dictfi.unam.mx; ahespriu@gmail.com; Phone/Fax: +52(55)56220850, ext. 111.
}

\begin{abstract}
Nitrate pollution is a worldwide problem in groundwater, as it may limit water supply and increase health risk when high concentrations are present. The North Maresme coastal alluvial groundwater-dependent agrosystem, one of the most heavily nitrate polluted aquifers in Spain, is located $70 \mathrm{~km}$ northeast from Barcelona. Field monitoring campaigns performed in this aquifer yielded nitrate concentrations up to ten times the permitted limit for drinking water suggested by the World Health Organization (50 mg/l), with a maximum concentration of $567 \mathrm{mg} / \mathrm{l}$ and a mean of $137.5 \mathrm{mg} / \mathrm{l}$. Nitrate contamination was quantified by means of a mass balance, taking into account the main hydrogeological and anthropogenic processes that control the behavior of this ion in the aquifer, such as recharge, groundwater extraction, irrigation and fertilizer application to crops. Nitrate balance is an integrative approach for assessing nitrate loading based on linking different sources of nitrates to a groundwater balance. This methodology considers nitrate as a conservative ion because the geological-geochemical medium behaves under oxidant conditions. Results show that the studied aquifer system receives, yields and retains approximately 935, 844 and 91 tons of $\mathrm{NO}_{3}^{-} /$year, respectively. This methodology can be applied to other nitrate-contaminated aquifers with similar conditions to improve management of fertilizers practices in areas of intensive agriculture.
\end{abstract}

Keywords: nitrate mass balance, nitrate contamination, groundwater balance, fertilizers, Maresme.

\section{Resumen}

La contaminación por nitratos en agua subterránea es un problema mundial, porque limita el abastecimiento del recurso e incrementa el riesgo a la salud humana cuando se presentan altas concentraciones disueltas. El sistema agrohidrológico activo del aluvial costero del Maresme Norte, uno de los acuiferos más severamente impactados por nitratos en España, se localiza a $70 \mathrm{~km}$ al noreste de Barcelona. Campañas de monitoreo han permitido establecer que este acuifero presenta concentraciones del ión nitrato hasta 10 veces superiores al límite máximo permisible sugerido por la Organización Mundial de la Salud (50 mg/l), con una concentración máxima de $567 \mathrm{mg} / \mathrm{l}$ y una concentración media del orden $137.5 \mathrm{mg} / \mathrm{l}$. La contaminación de nitratos se cuantificó por medio de un balance de masas, considerando los procesos primarios hidrogeológicos y antropogénicos que controlan el comportamiento de este ión en el acuifero, tales como la recarga, extracción del agua subterránea, irrigación e incorporación de fertilizantes agroquímicos a cultivos. El balance de nitratos representa un enfoque integrador de estudio donde se han vinculado las diferentes fuentes de 
este compuesto a un balance subterráneo. La metodología desarrollada considera al nitrato como un ión conservativo, porque las condiciones geológicas e hidrogeológicas del acuifero son oxidantes. Los resultados muestran que el acuifero estudiado recibe, cede y retiene aproximadamente 935, 844 y 91 t de $\mathrm{NO}_{3}^{-}$- año, respectivamente. Esta metodología puede ser aplicada a otros acuíferos semejantes contaminados por nitratos, como una herramienta útil para optimizar las prácticas de gestión y aplicación de fertilizantes agroquímicos en áreas de intensa actividad agrícola.

Palabras Clave: balance de masas y/o nitratos, contaminación por nitratos, balance de aguas subterráneas, fertilizantes, Maresme.

\section{Introduction}

Groundwater is a fundamental component of the hydrologic cycle. Due to its characteristics of storage, circulation, origin and collection, it is generally considered a secure, reliable and economic source of water supply for a variety of uses, which range from urban supply to agricultural uses. Aquifers are, however, subject to anthropogenic impacts, including contamination. Different chemical compounds bring different concerns. Nitrogen $(\mathrm{N})$ is particularly interesting, as $\mathrm{N}$ inputs in groundwater systems may stem from a variety of activities. For instance, nitrogen input is often perceived as essential to underpin agricultural practices (Crawford, 1995; Pang and Letey, 2000). Excessive $\mathrm{N}$ fertilizer application is thus, common in intensive vegetable and fruit producing areas (Ju et al., 2006). Other sources of nitrogen include animal manure and pollution from septic and sewage discharges.

Nitrogen presents different oxidation states, being nitrate the most stable form. Many studies have shown high correlation between agriculture and high nitrate concentrations in groundwater (Oakes and Young, 1981; Bundy et al., 1994; Voudouris et al., 2004; Torr, 2009). Extensive use of fertilizers is considered to be the main source of nitrates that reach groundwater worldwide (Almasri, 2007; Darnault et al., 2005; Carey et al., 2009). However, nitrate pollution is not restricted to rural areas; untreated sewage of urban areas is characterized by high contents of $\mathrm{NH}_{4}^{+}$. When filtration takes place, this compound is oxidized to $\mathrm{NO}_{3}{ }^{-}$in the subsoil and may enter directly into the saturated zone of aquifers (Foppen, 2002).

Nitrate is a soluble and negatively charged ion and thus, has high mobility and leaching potential from the unsaturated zone (Joekar-Niasar and Ataie-Ashtiani, 2009). This process is a complex interaction of many variables such as land use practices, on-ground $\mathrm{N}$ loading, groundwater recharge, soil nitrogen dynamics, soil characteristics and depth to the water table (Herbei and Spalding, 1993; Chesnaux and Allen, 2008). Further complexity is added by temporal variations in the behavior of these parameters. Usually, nitrate undergoes a denitrification process in the unsaturated zone, depending on the properties and prevailing conditions (Ryan, 1994; Kim and Burguer, 1997; Puckett et al., 1999; Sanchez-Perez et al., 1999; Foppen, 2002; Singleton et al., 2007; Gates et al., 2008).
Over the years, mass-balance budget methodologies have become a common alternative to quantify $\mathrm{N}$ sources in the environment. In fact, there is a great need to perform this kind of studies in agro-ecosystems at various scales to better understand the role of groundwater as a source and/or sink for $\mathrm{N}$ in the environment and to improve $\mathrm{N}$ management strategies for water quality purposes (Puckett et al., 1999). Surprisingly, there are not many authors that have reported explicitly underground nitrate mass balance approaches in the literature, most likely due to a general lack of reliable hydrogeological data. Instead, mass balance methodologies have been applied in the vadose zone. These often aim at predicting the risk of nitrate leaching into groundwater (see Barry et al., 1993; Puckett et al., 1999; Ju et al., 2006; and others).

However, there are examples of mass balance methodologies applied to other non-conservative ions evaluating the pollutant loading in the environment. For example, Suchanek et al. (2010) performed a mass balance mercury budget for the Sulphur Bank Mercury Mine (California, USA), in order to determine the $\mathrm{Hg}$ loading to Clear Lake.

In Spain, groundwater-based irrigation accounts for a total of 3500 million cubic meters per year $\left(\mathrm{Mm}^{3} /\right.$ year), corresponding to an area of 700000 hectares (ha). For combined irrigation systems with surface and groundwater the variability is greater, as is the availability of surface water, with a maximum of $1100 \mathrm{Mm}^{3}$ in dry years. This corresponds to about $10^{6}$ ha, almost one third of the total Spanish irrigation. In Catalonian catchments, groundwater has long supported over $90 \%$ of irrigation water consumption (Martínez-Beltrán, 1993). These numbers clearly reveal the strategic importance of groundwater, and imply the need to protect its quality from contamination.

Nitrate pollution has become increasingly common in groundwater systems. It is of no surprise that nitrate contamination extends throughout the majority of Catalonian groundwater systems, mostly due to the excessive use of agrochemical fertilizers (Penuelas et al., 2009). This is particularly true for the North Maresme, South Maresme and Tordera aquifers, where relatively recent monitoring campaigns show that $70.5 \%, 75 \%$ and $39.1 \%$ of the sampling points exceeded the threshold recommended by the World Health Organization $(50 \mathrm{mg} / \mathrm{l})$ for drinking water (De Miguel and Payer, 2002). Other studies show that 
nitrate concentrations in groundwater samples from $22 \%$ of the agricultural area exceeded drinking water threshold (Laegreid et al., 1999).

The aims of this paper are: (1) to perform a groundwater mass-balance budget in order to evaluate dissolved nitrate contamination in a heavily polluted aquifer of the region; and (2) to improve the hydrogeological conceptual model of the system in order to assess nitrate loading. The application of this methodology links water budget components to the nitrate mass balance as nitrate sources. It uses general considerations related to transport and conservation of nitrate, in order to differentiate the magnitude of $\mathrm{N}$ sources and establish priorities in the control of these sources in the area.

\section{Study area}

The Maresme aquifer is a $5 \mathrm{~km}$ long coastal strip located $70 \mathrm{~km}$ northeast of Barcelona, Spain (Figure 1). The aquifer consists of pervious alluvial and coastal sediments bounded from north to southwest by impermeable materials of the Catalonian Mountain Range, and to the southeast by the Mediterranean Sea. The Maresme aquifer comprises four municipalities: Calella, Santa Susanna, Pineda de Mar and Malgrat de Mar, all with a strong agricultural tradition.

The geological setting is dominated by detrital Quaternary sediments from transient streams, erosion of the granitic basement and transitional deposits of coastal terraces and beaches. The northern part of the area bounds with the Catalonian Range and consists of granite and posttectonic granodiorites between Calella and Santa Susanna, and Paleozoic materials (slate, limestone and inter-bedded detrital sand-clay materials) from Santa Susanna to Malgrat. Upper Cambrian and Ordovician slates constitute the oldest materials in the study area (Figure 2).

The conceptual model has been described by Custodio (1982), Guimerà and Candela (1989), Guimerà (1992), Guimerà et al. (1995), and Guimerà (1998). The aquifer extends over an area of $12 \mathrm{~km}^{2}$ and consists of an unconfined

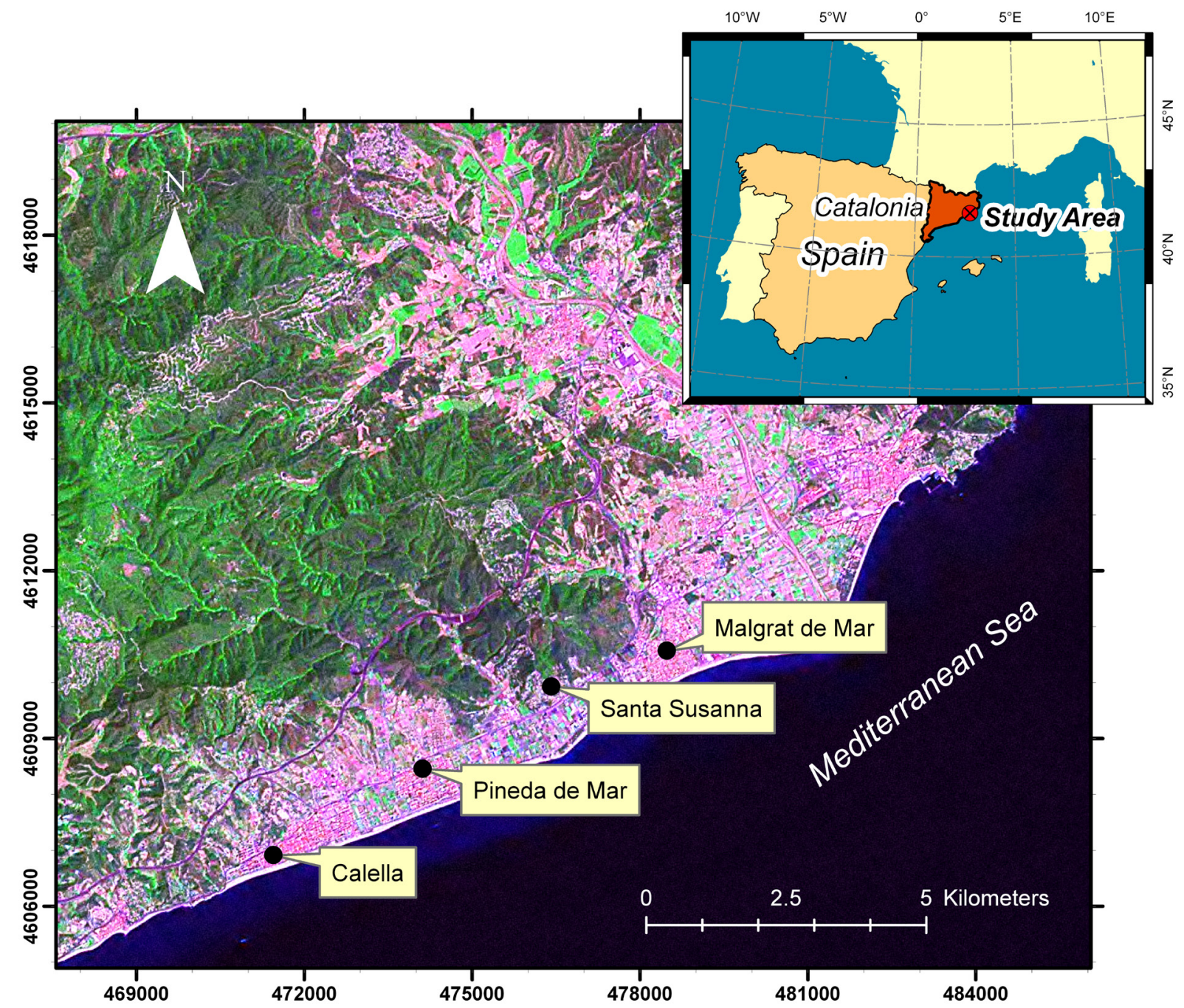

Figure 1. Location of the study area. Satellite image from Landsat Geocover (Global Land Cover Facility) ETM+2000 Mosaics original rights USGS. 


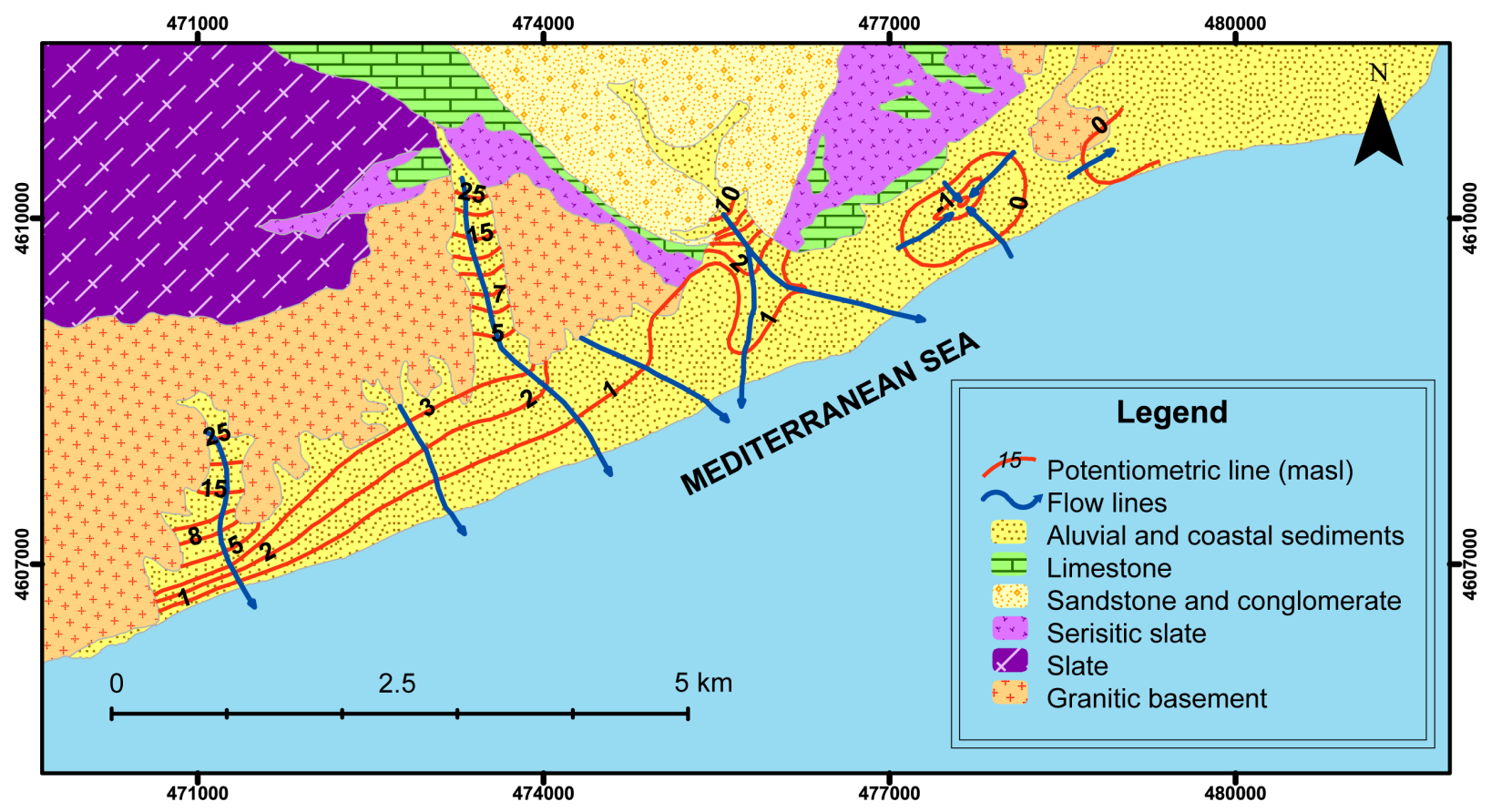

Figure 2. Geology and potentiometric surface (May, 2004) of the North Maresme aquifer.

layer of granular deposits (medium sand, gravel with scarce silt-clay matrix and altered felsic rocks). Along the coast, lithology is represented by coastal terraces and beaches composed of medium sand and poorly consolidated gravels ground by the sea. The alluvial plain and the coast are hydraulically connected and behave as one hydrogeological unit. Depth to water table varies from 7 to $16 \mathrm{~m}$ in the alluvial zone (near the contact with the Catalonian Range) to $4 \mathrm{~m}$ close to the coast. Saturated thickness is approximately $10 \mathrm{~m}$.

The aquifer is underlain by an aquitard that consists of randomly distributed silty lenses embedded in a clay matrix. This unit is $30 \mathrm{~m}$ thick, its distribution and in-depth geometry has received little attention. Finally, the bedrock is composed of granite and granodiorite rocks. The depth at which the basement can be reached is variable, ranging from 5 to $10 \mathrm{~m}$ in the north and northwestern zones to $20-25 \mathrm{~m}$ near the coast. The top of the bedrock unit consists of a $5 \mathrm{~m}$ thick sandy layer that may allow groundwater circulation.

\section{Materials and Methods}

\subsection{Hydrogeological data collection}

A variety of bibliographic and cartographic sources were consulted prior to field work. These included thematic mapping, existing research projects of the South and North Maresme area (Villarroya, 1986; Guimerà, 1992), scientific papers and different monitoring reports ( $\mathrm{Da}$ Costa and García, 1990; Villabona and Jimenez, 1998; De Miguel and Payer, 2002).

Hydrogeological data was collected through five field campaigns carried out between February and May of 2004. Thirty-three large-diameter (1-3 m) partially penetrating wells and one spring were identified. A database was generated with information on water table level, well depth, casing diameter, and approximate extraction flow rates in order to select the best sites for hydrogeochemical sampling. Field data was used to estimate hydraulic head (referred to mean sea level) in order to determine the potentiometric surface of the aquifer.

\subsection{Spatial distribution of hydraulic conductivity}

Due to problems of pumping tests associated with large diameter partially penetrating wells, the spatial distribution of hydraulic conductivity $(k)$ was estimated from the specific capacity of wells $(q)$. Custodio and Llamas (1983) state that in small diameter wells (between 0.1 and $0.5 \mathrm{~m}$ ), transmissivity $(T)$ is approximately 1.4 times the specific capacity. Also, it is therefore common to associate the specific capacity directly with the transmissivity parameter, in large diameter wells $(>1 \mathrm{~m})$.

Spatial variation of hydraulic conductivity was analyzed by determining the specific capacity from 17 wells. At a field level, constant flow rate pumping $(Q)$ was carried out. After steady state condition was reached, maximum drawdown $\left(s_{w}\right)$ was measured, and transmissivity and hydraulic conductivity of the aquifer was calculated according to the following equations: 


$$
\begin{aligned}
T & =\frac{Q}{S_{w}} \\
k & =\frac{T}{b}
\end{aligned}
$$

where $T$ is the transmissivity $\left[L^{2} T^{-1}\right], Q$ the flow rate $\left[L^{3} T^{-1}\right],_{s w}$ the maximum drawdown within the well $[L], k$ the hydraulic conductivity $\left[L T^{-1}\right]$ and $\mathrm{b}$ the saturated thickness of the aquifer $[L]$.

\subsection{Hydrogeochemical characterization}

Hydrogeochemical characterization was carried out by means of 15 water samples from selected wells. Anions $\left(\mathrm{HCO}_{3}^{-}, \mathrm{SO}_{4}^{-2}, \mathrm{Cl}^{-}, \mathrm{NO}_{3}^{-}\right)$, cations $\left(\mathrm{Na}^{+}, \mathrm{K}^{+}, \mathrm{Ca}^{+2}, \mathrm{Mg}^{+2}\right)$, electrical conductivity $(E C)$ and $\mathrm{pH}$ were analyzed at the Water Quality Laboratory of the Catalonian Water Agency. $\mathrm{EC}$ and $\mathrm{pH}$ were also measured at site with a handheld Combo pH \& CE Brand potentiometer. Samples were taken with a one-liter bailer and transported at $4{ }^{\circ} \mathrm{C}$ for further analysis.

The concentrations of major ions were plotted in Piper (Piper, 1944) and Stiff (Stiff, 1951) diagrams. The Piper diagram was modified by adding concentrations of $\mathrm{NO}_{3}{ }^{-}$and $\mathrm{SO}_{4}^{-2}$ in the field of the anions where usually only $\mathrm{HCO}_{3}^{-}$ $+\mathrm{CO}_{3}^{-2}, \mathrm{Cl}^{-}$and $\mathrm{SO}_{4}^{-2}$ are included, in order to assess the influence of both ions in the composition of groundwater.

\subsection{Groundwater and nitrate mass balance}

A groundwater balance of the aquifer was developed to estimate the individual flow and $\mathrm{NO}_{3}{ }^{-}$sources of the hydrogeological system. The mass conservation equation was used to determine the storage variation of groundwater in the aquifer:

$$
\pm \Delta S=\sum_{i=1}^{5} I-\sum_{i=1}^{3} O
$$

where $I$ and $O$ represent the water inputs and outputs of the aquifer, and $\Delta S$ is the storage variation of the system. The following inputs were considered: (1) recharge from rainfall, (2) contribution from surficial drainage (streams in Santa Susanna and Pineda de Mar), (3) lateral inflows from other hydrogeological units (altered granite), (4) irrigation returns and (5) losses from the supply network. Outputs included (1) groundwater abstraction for urban supply and agricultural use and (2) groundwater discharge into the Mediterranean Sea.

The annual flow that surface streams yield to the aquifer and the natural discharge into the Mediterranean Sea were estimated by applying Darcy's Law (Darcy, 1856). On the other hand, recharge estimations were performed by means of a hydrometeorological analysis based on a 20 year series of daily precipitation and temperature data. This information was used to estimate the potential evapotranspiration (ETP) using Thornthwaite's method (Thornthwaite, 1948). Because no hydrometric data from main streams was available, rainfall infiltration was estimated as the difference between annual precipitation and annual ETP applied to the net infiltration aquifer extent (omitting impermeable urban areas), and taking into account the capacity of the soil to infiltrate and retain water as estimated by Guimerà (1992). Field capacity, initial moisture content, mean thickness of soil cover, permanent wilting point and lamination value were considered in the above mentioned calculation.

The second part of the mass balance analysis was performed to determine the nitrate loading in the aquifer throughout time (equation 4). Nitrate is assumed to behave as a conservative ion because the geological-geochemical medium presents oxidant conditions (Guimerà, 1992, 1998; Vitòria et al., 2003):

$$
\pm \Delta \mathrm{NO}_{3}^{-}=\sum_{i=1}^{5} I-\sum_{i=1}^{2} \mathrm{O}
$$

where $I$ and $O$ represent the $\mathrm{NO}_{3}^{-}$ion inputs and outputs of the aquifer, and $\mathrm{ANO}_{3}^{-}$represents the nitrate storage variation in the system.

The following inputs were considered: (1) incorporation of nitrate by fertilizers, estimated from the amount of inorganic $\mathrm{N}$ (derived from fertilizers) necessary and/or recommended for each type of crop (De Miguel and Payer, 2002) and the cultivated extent for each crop in the study area as provided by the corresponding Municipal Delegations, (2) mineralization and nitrification, including the production of $\mathrm{NO}_{3}{ }_{3}^{-}$from the soil's own oxidizing condition, estimated from a nitrification rate obtained experimentally in the study area by Guimerà (1992), (3) content of $\mathrm{NO}_{3}^{-}$by irrigation returns to the aquifer, estimated as the product between irrigation returns and the mean concentration of nitrate obtained from groundwater sampling, (4) potable water and sewage network losses, and (5) nitrate incorporation by rainfall infiltration. All inputs were estimated as the product of the water volume of each input previously calculated from the groundwater balance, times the representative nitrate concentration of each term reported and communicated by Guimerà (1992, 2004 -oral communication-, respectively).

Outputs included were: (1) $\mathrm{NO}_{3}{ }^{-}$crop uptake, estimated by the percentage of $\mathrm{N}$ lost by leaching and the percentage retained by crops, using the assumptions developed by Custodio (1982) and applied by Guimerà and Candela (1989), and (2) extractions of $\mathrm{NO}_{3}^{-}$by groundwater abstraction, estimated by multiplying the annual average of groundwater extraction, times the mean $\mathrm{NO}_{3}^{-}$concentration obtained from sampling. Natural attenuation by denitrification was considered negligible due to the oxidizing nature of the environment. Calculation details for each input and output will be further discussed in section 4.3. 


\section{Results and Discussion}

\subsection{Spatial distribution of hydraulic conductivity}

According to the field campaign carried out, the potentiometric surface for May 2004 is depicted as a set of equipotential curves parallel to the coastline with a primary northeast-southwest orientation. A progressive decrease in hydraulic head is observed from the recharge area in the mountains to the coast, from 25 to 1 masl (Figure 2). Hydraulic gradients are smoother in the coastal sector $(0.004$ $\mathrm{m} / \mathrm{m}$ ), corresponding to the higher hydraulic conductivity areas (Figure 3). Conversely, the gradient is steeper in the lower permeability areas.

Natural groundwater discharge to the Mediterranean Sea occurs between Calella and Pineda de Mar, having a preferential northwest-southeast direction as opposed to what occurs between Santa Susanna and Malgrat, where hydraulic heads are below sea level $(-0.9 \mathrm{~m})$. This is interpreted as an elongated pumping cone which can be inferred from intensive groundwater extraction. This causes groundwater flow to converge towards the center of the depression cone and prevents natural discharge to the sea in this area.

Based on hydraulic conductivity and transmissivity values (Figure 3) the aquifer was divided into three zones as per the conceptual groundwater flow model previously described. Zone I corresponds to the strip that runs parallel to the coastline. This area presents high hydraulic conductivities (50 and $200 \mathrm{~m} /$ day), corresponding to transmissivities on the order of 500 to $2000 \mathrm{~m}^{2} /$ day. Zone II presents a moderate hydraulic conductivity corresponding to the transition zone between the coastal and alluvial sediments. Permeability for this sector ranges between 10 and $70 \mathrm{~m} /$ day, equivalent to transmissivities between 100 and $700 \mathrm{~m}^{2} /$ day. Finally, zone III shows low hydraulic conductivity values and is associated with the higher topographic area. Permeability ranges between 5 and 10 $\mathrm{m} /$ day, corresponding to transmissivity values of 50 to 100 $\mathrm{m}^{2} /$ day.

\subsection{Hydrogeochemistry}

Table 1 shows results of hydrogeochemical analyses of sampled wells. An electrical error balance between 0.01 and $6.3 \%$ (mean value $=3.98 \%$ ) suggests that no major elements were missing from the chemical analysis. Areas with maximum $\mathrm{NO}_{3}^{-}$concentrations are located towards the center and northeastern side of the coastal strip, with extensions of 1.25 and $0.69 \mathrm{~km}^{2}$, respectively (Figure 3). These are best described as two semi-elliptical pollutant plumes of anthropogenic origin. Compared to previous studies (De Miguel and Payer, 2002), these results imply an increase of $300 \mathrm{mg} / \mathrm{l}$ for the Pineda de Mar and the Santa Susanna stream areas over the last decade. Concentrations remain stable for the northeastern zone (between Santa Susanna and Malgrat).

The spatial variation of chemical composition of groundwater is shown in the modified Stiff polygon map (Figure 4). A spatial variation of hydrochemical facies can be observed from $\mathrm{Ca}^{2+}-\mathrm{HCO}_{3}^{-}$in the recharge zone to

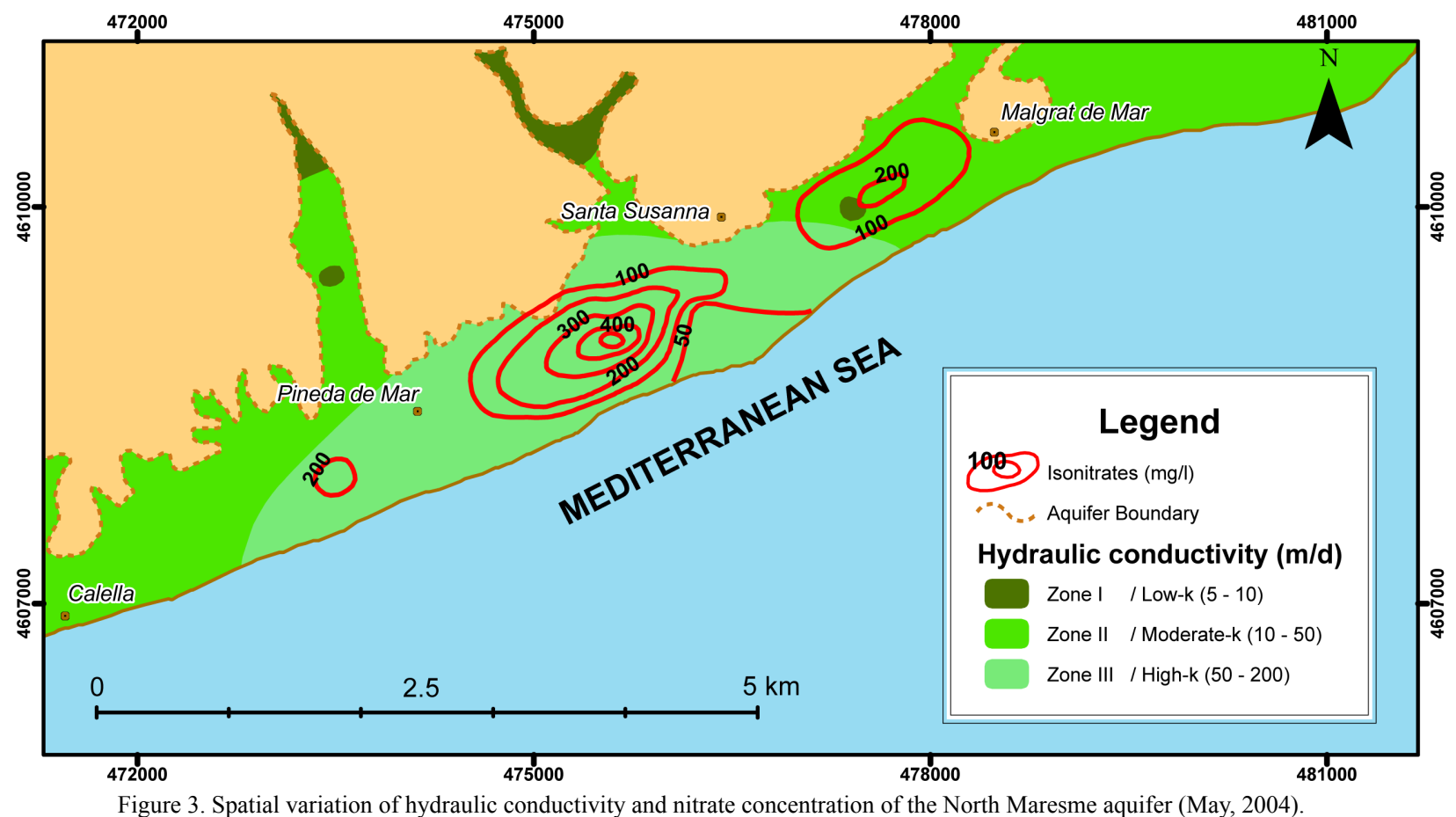

Figure 3. Spatial variation of hydraulic conductivity and nitrate concentration of the North Maresme aquifer (May, 2004). 
Table 1. Analytical results of groundwater sampling (Concentrations in $\mathrm{mg} / \mathrm{l}$ )

\begin{tabular}{ccccccccccccc}
\hline Well & $\mathrm{X}(\mathrm{UTM})$ & $\mathrm{Y}(\mathrm{UTM})$ & $\mathrm{CE}(\mu \mathrm{S} / \mathrm{cm})$ & $\mathrm{HCO}_{3}^{-}$ & $\mathrm{SO}_{4}^{-2}$ & $\mathrm{Cl}^{-}$ & $\mathrm{NO}_{3}^{-}$ & $\mathrm{Na}^{+}$ & $\mathrm{K}^{+}$ & $\mathrm{Ca}^{+2}$ & $\mathrm{Mg}^{+2}$ & Error $(\%)^{1}$ \\
\hline CA-1 & 471110 & 4608175 & 1281 & 158.4 & 271 & 119.3 & 236.4 & 35.54 & 1.33 & 211.8 & 49.9 & 5.53 \\
CA-2-bis & 471215 & 4607643 & 1190 & 214.1 & 150 & 162.9 & 155.5 & 51.39 & 1.83 & 176.3 & 40.6 & 5.11 \\
CA-4 & 473395 & 4607915 & 1337 & 283.5 & 272 & 112.5 & 201.5 & 46.4 & 9.09 & 236.8 & 42.1 & 4.87 \\
PI-9bis & 473490 & 4610180 & 754 & 229.4 & 154 & 48.2 & 62.5 & 19.22 & 1.17 & 137.9 & 26.2 & 6.14 \\
Pl-10-bis & 473620 & 4608795 & 738 & 231.2 & 124 & 58.5 & 58.7 & 20.23 & 1.23 & 124.9 & 28.9 & 6.23 \\
Pl-12 & 475015 & 4608585 & 1353 & 209.2 & 280 & 135 & 242.4 & 41.18 & 1.54 & 255 & 37.7 & 4.15 \\
Pl-13 & 475133 & 4608608 & 1772 & 348.7 & 361 & 207.9 & 257.6 & 95.03 & 1.99 & 321 & 41.8 & 1.87 \\
SA-24 & 476410 & 4609385 & 1140 & 190 & 191 & 146.8 & 154.6 & 58.66 & 2.41 & 166.8 & 38.7 & 3.07 \\
SA-15-bis & 475645 & 4608941 & 1255.5 & 185.6 & 530 & 263.1 & 566.9 & 124.3 & 2.97 & 355.7 & 89.2 & -0.01 \\
SA-19 & 475815 & 4609895 & 1170 & 487.8 & 80 & 164 & 32.4 & 47.77 & 1.51 & 190.1 & 50.2 & 6.3 \\
SA-22 & 476225 & 4609225 & 742 & 182.8 & 103 & 99.1 & 50.1 & 44.28 & 1.74 & 99.6 & 23.7 & 1.86 \\
SA-26 & 476840 & 4609770 & 1085 & 339.9 & 150 & 106.2 & 92.2 & 56.66 & 4.89 & 179 & 29.2 & 5.72 \\
SA-Man & 475135 & 4610485 & 850 & 228.6 & 108 & 106.7 & 66.5 & 54.5 & 1.87 & 112.7 & 27.8 & 2.68 \\
MA-29 & 477895 & 4610215 & 973 & 116.7 & 153 & 114.6 & 157.2 & 47.29 & 7.54 & 144.6 & 24.6 & 5.79 \\
MA-30 & 478765 & 4610565 & 678 & 160.9 & 78 & 70.3 & 54.3 & 45.08 & 25.22 & 70.7 & 12.1 & 0.3 \\
\hline
\end{tabular}

${ }^{1}$ Chemical error analysis, estimated with the equation:

$E(\%)=\frac{\sum c a t-\sum a n}{\sum c a t+\sum a n} \cdot 200$

Where $c a t=$ Cations $(\mathrm{meq} / \mathrm{l})$, and $a n=$ Anions $(\mathrm{meq} / \mathrm{l})$

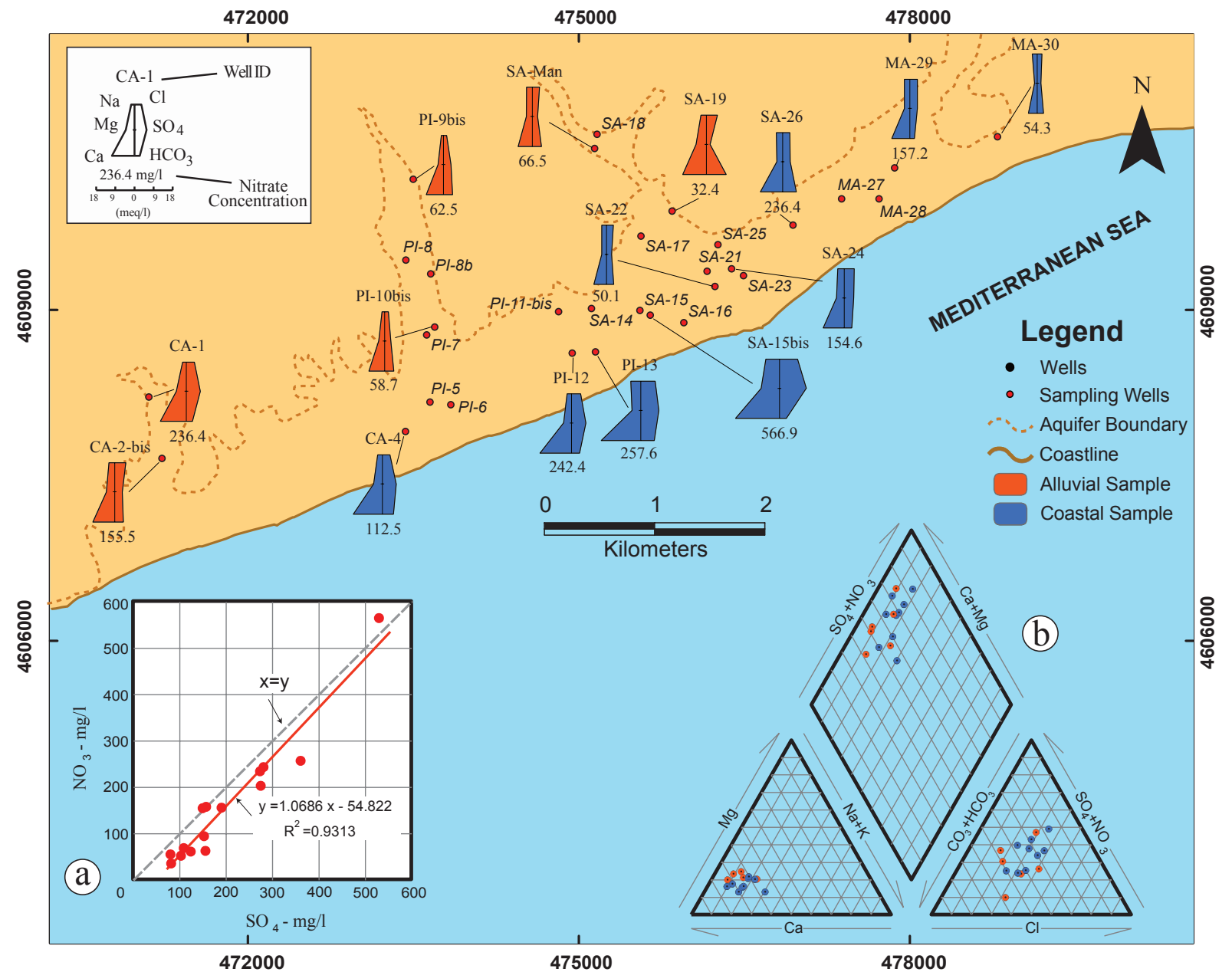

Figure 4. Spatial variation of the hydrogeochemical composition in the studied aquifer. (a) Nitrate-sulfate correlation, (b) Modified Piper diagram. 
$\mathrm{Ca}^{2+}-\mathrm{NO}_{3}-\mathrm{SO}_{4}^{-2}$ in the alluvial zone, which in turn is subject to agricultural activities.

Nitrate concentration of groundwater range between 32.4 and $567 \mathrm{mg} / 1$, with an average of $137.5 \mathrm{mg} / 1$ (over 10 times the allowable limit for drinking water established by the World Health Organization). Only one out of the sixteen samples had a nitrate concentration below the limit (32 mg/l).

On the other hand, there is a strong correlation between $\mathrm{NO}_{3}{ }^{-}$and $\mathrm{SO}_{4}^{-2}$ (Figure 4a). This implies that sulfates sources are mostly agricultural practices. Ammonium sulfate $\left[\left(\mathrm{NH}_{4}\right)_{2} \mathrm{SO}_{4}\right]$ is an inorganic salt contained in soil fertilizers. It has $21 \%$ nitrogen as ammonium cations and $24 \%$ sulfur as sulfate anions. Sulfate anions are easily washed out by rainwater and excess irrigation, favoring infiltration through the unsaturated zone.

The modified Piper diagram (Figure $4 \mathrm{~b}$ ) shows three hydrochemical facies. These can be associated with the degree of nitrate contamination of the aquifer: (1) $\mathrm{Ca}^{2+}$ $\mathrm{HCO}_{3}^{-}$facies, found at the recharge zone (sample SA19); (2) $\left(\mathrm{NO}_{3}^{-}\right.$and/or $\left.\mathrm{SO}_{4}^{-2}\right) \mathrm{Ca}^{2+}-\mathrm{HCO}_{3}^{-}$facies, found in samples taken at topographic highs and also in transitional groundwater zones between the alluvial plain and the coastal line; and (3) $\mathrm{Ca}^{2+}-\mathrm{NO}_{3}-\mathrm{SO}_{4}{ }^{-2}-\mathrm{Ca}^{2+}$ facies, located in the coastal strip, where the degradation of the quality of the aquifer is highly associated with intense agricultural activity.

Besides agriculture, there are hydrogeological factors involved with the presence and distribution of $\mathrm{NO}_{3}$ concentrations in the area. Higher nitrate concentrations are found at the most superficial levels of the saturated zone. These are controlled by lower hydraulic heads and shallower well depths. In consequence, nitrate concentrations seem to be stratified in the saturated zone, within the first two meters, in wells no deeper than $10 \mathrm{~m}$.

Presence and distribution of nitrates are associated with water table fluctuations of the aquifer. Two main processes were identified. As noted in Figure 5a (well SA-19), an increase in the concentration of both nitrate and sulfate ions is observed, as hydraulic head rises over a non-continuous period of 14 years. This process suggests $\mathrm{NO}_{3}^{-} \mathrm{SO}_{4}^{-2}$ ions present in the vadose zone are incorporated into the aquifer as the water table rises. Well SA-26 (Figure 5b) shows similar behavior from 1990 to 2002 . For the next two years, however, the trend is inverted, attributed to the effect of recharge periods.

\subsection{Nitrate mass balance}

Several sources of nitrate were analyzed and estimated considering annual average values for each element. This was done by means of the mass balance, which allows computing the total amount of nitrate that the aquifer yields and receives per year. Figure 6 shows the results of the groundwater balance with all the components considered. Inputs and outputs of $\mathrm{NO}_{3}^{-}$are illustrated in Figure 7.
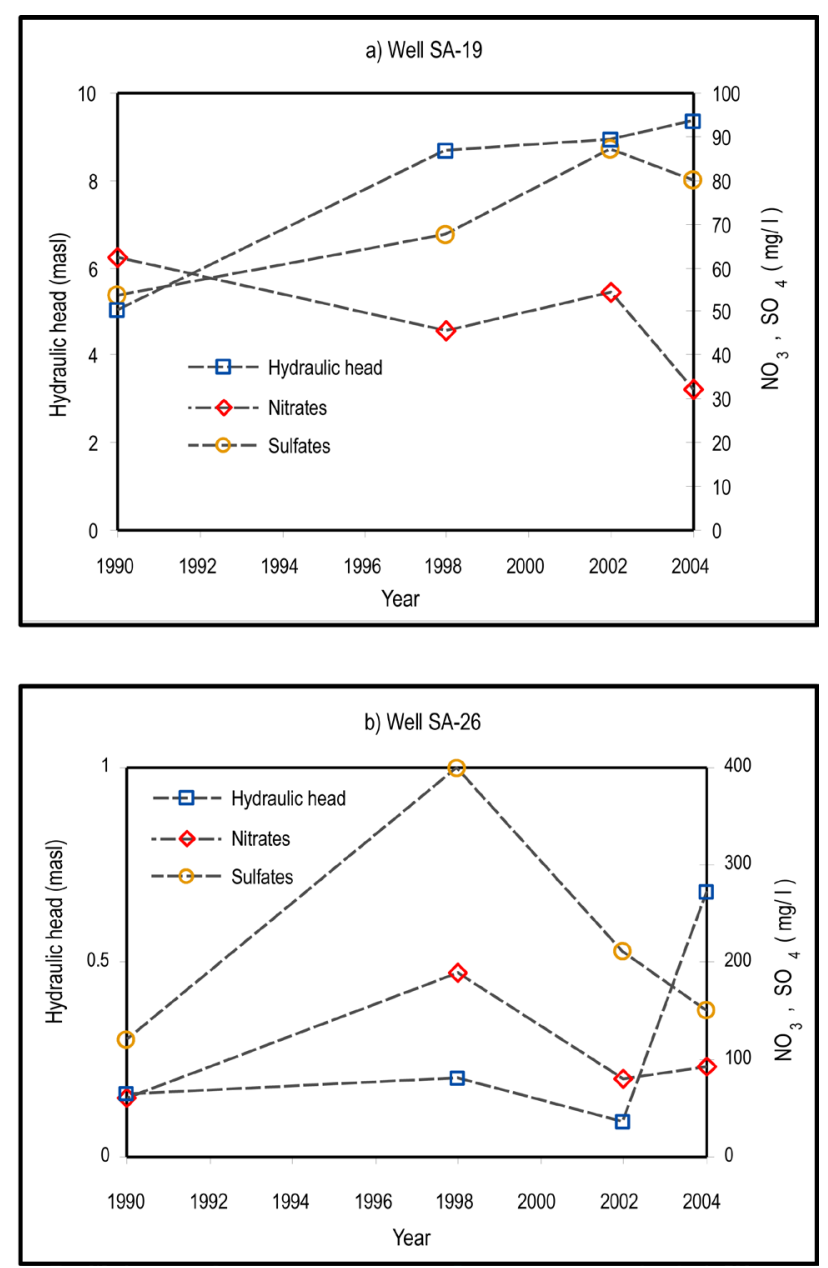

Figure 5. Nitrate concentration associated with water table fluctuations in the North Maresme aquifer.

\subsubsection{Inputs}

Addition of nitrate by fertilizers and addition of nitrogen compounds by agrochemicals is the most important term of the nitrate balance, as determined by a positive relation with agricultural land use (Oakes and Young, 1981; Kolpin, 1997). This term was estimated from the amount of inorganic $\mathrm{N}$ (derived from fertilizers) necessary and/ or recommended for each type of crop and the cultivated extent for each crop in the study area. As shown in Table 2 , the amount of inorganic $\mathrm{N}$ applied to agricultural fields is $3255 \mathrm{~kg}$ of N/year/ha (De Miguel and Payer, 2002). The different types of crops in the study area and their respective crop surface were provided by the corresponding Municipal Delegations (Table 2). It was estimated that for each metric ton of $\mathrm{N}$ applied, $4.42 \mathrm{t}$ of $\mathrm{NO}_{3}^{-}$/year are produced and have the potential to be incorporated into the aquifer.

Total extent of cultivated land is 796 ha where an estimated total of $153 \mathrm{t}$ of N/year were applied through the use of fertilizers, equaling a total of $677 \mathrm{t}$ of $\mathrm{NO}_{3}^{-}$that can be incorporated into the aquifer.

Custodio (1982), Guimerà and Candela (1989) reported a mean input value of $1000 \mathrm{~kg}$ of N/year/ha due to the 


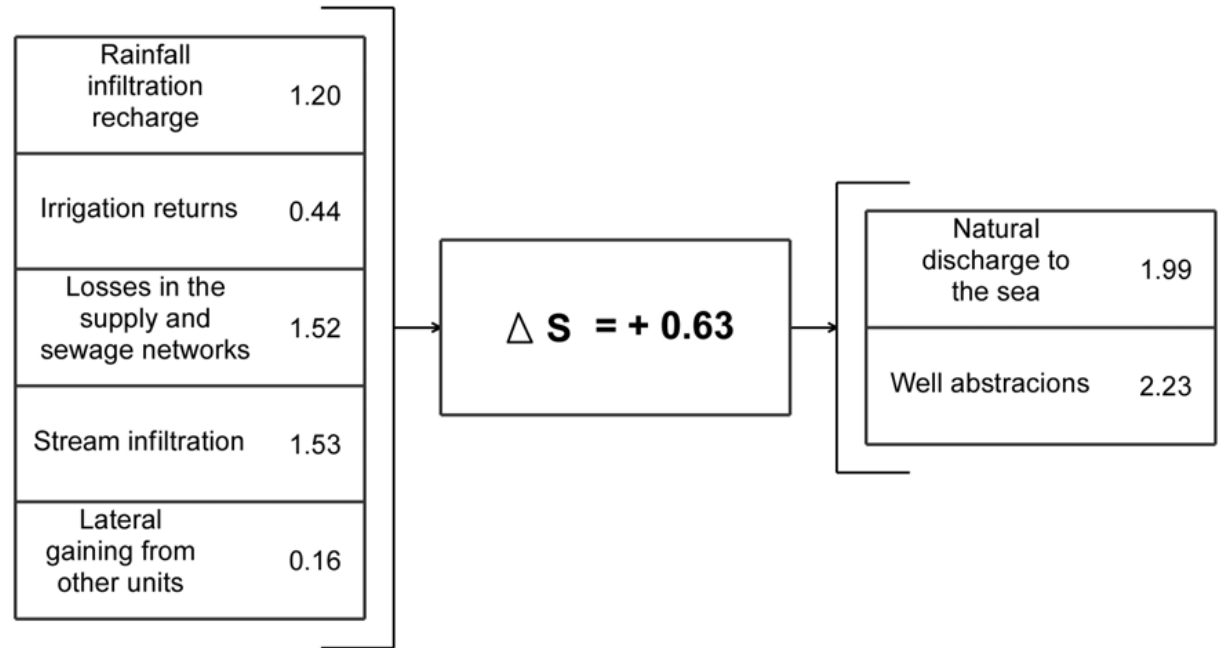

Figure 6. Results of the groundwater balance performed in the North Maresme aquifer (2004). Values in Mm³/year

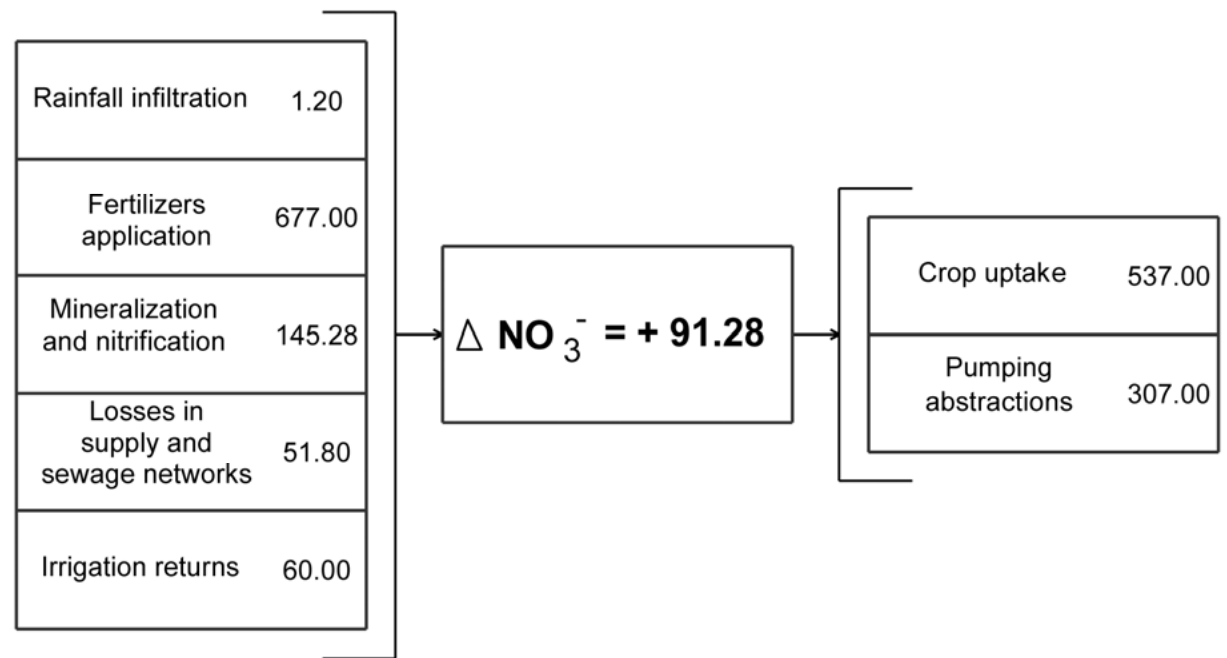

Figure 7. Results of the nitrate mass balance performed in the North Maresme aquifer (2004). Values in metric tons of $\mathrm{NO}_{3}^{-/} /$year

application of fertilizers in the Catalonia coastal aquifers, including the Maresme hydrogeological system. Similarly, Ju et al. (2006) studied the annual N budget and groundwater nitrate-N concentrations in three major intensive cropping systems in Shandong province, north China. These authors reported values of $\mathrm{N}$ inputs from fertilizers of 1358, 661 and $553 \mathrm{~kg}$ of N/year/ha, respectively. As noted, the North Maresme aquifer system represents 3.2 and 2.4 times of the compared $\mathrm{N}$ inputs respectively, which shows that the studied area has a significantly increasing overburden of fertilizers.

The second most important term is mineralization and nitrification. This considers the production of nitrates from the oxidizing conditions in soils. In the region soils have a density of $1.56 \mathrm{t} / \mathrm{m}^{3}$, an average thickness of $0.65 \mathrm{~m}$, and a nitrification rate of $18 \mathrm{mg}$ of $\mathrm{NO}_{3}^{-} / \mathrm{kg} /$ year. According to these values obtained experimentally by Guimerà (1992), nitrification can provide a total of $145.28 \mathrm{t} / \mathrm{NO}_{3}^{-} /$year for the 796 ha of cultivated land in the study area.

In order of importance, irrigation returns is the third nitrate input into the aquifer. According to data supplied by the Municipal Delegations and the hydrogeological balance carried out in this research, $20 \%$ of the water allocated for irrigation $\left(2.23 \mathrm{Mm}^{3} /\right.$ year $)$ returns to the aquifer as direct recharge. This represents a total volume of $0.44 \mathrm{Mm}^{3}$. Since groundwater is used for irrigation, the mean concentration of $137.5 \mathrm{mg} / \mathrm{l}$ of $\mathrm{NO}_{3}{ }^{-}$obtained from the groundwater sampling campaign was used to calculate the total amount of nitrates for this input, which yields $60 \mathrm{t}$ of $\mathrm{NO}_{3}^{-} /$year. This is assumed to percolate into the aquifer.

The following term of nitrate input into the aquifer is the leakage from drinking water and sewage networks. Although water flowing through the drinking water network is considered to be drinkable, it still has a slight concentration (about $10 \mathrm{mg} / \mathrm{l}$ ) of dissolved $\mathrm{NO}_{3}^{-}$(Guimerà, 1992, 2004 -oral communication, Barcelona, Spain-). 
Table 2. Nitrogen allocations for crop type at the study area

\begin{tabular}{|c|c|c|c|c|c|c|c|}
\hline Crop & $\begin{array}{l}\text { Area at Calella } \\
\text { (ha) }\end{array}$ & $\begin{array}{c}\text { Area at Pineda } \\
\text { de } \text { Mar }^{1} \\
\text { (ha) }\end{array}$ & $\begin{array}{c}\text { Area at Santa } \\
\text { Susanna }^{1} \\
\text { (ha) }\end{array}$ & $\begin{array}{l}\text { Area at Malgrat } \\
\text { (ha) }\end{array}$ & $\begin{array}{c}\text { Total area per } \\
\text { crop type } \\
\text { (ha) }\end{array}$ & $\begin{array}{c}\text { Recommended allocation } \\
\text { per crop }{ }^{2} \\
\text { (kg of } \mathrm{N} / \mathrm{ha} / \text { year })\end{array}$ & $\begin{array}{c}\text { Total consumption } \\
\text { (t of N/year) }\end{array}$ \\
\hline Potato & 10 & 35 & 37 & 86 & 168 & 200 & 33.6 \\
\hline Tomato & 6 & 34 & 31 & 35 & 106 & 200 & 21.2 \\
\hline Pepper & 2 & 1 & 1 & 1 & 5 & 250 & 1.25 \\
\hline Cucumber & 1 & 0 & 3 & 2 & 6 & 280 & 1.68 \\
\hline Lettuce & 4 & 25 & 17 & 39 & 85 & 140 & 11.9 \\
\hline Spinach & 1 & 2 & 2 & 11 & 16 & 180 & 2.88 \\
\hline Onion & 4 & 17 & 7 & 16 & 44 & 160 & 7.04 \\
\hline Garlic & 0 & 2 & 2 & 0 & 4 & 130 & 0.52 \\
\hline Carrot & 1 & 3 & 3 & 4 & 11 & 100 & 1.1 \\
\hline Cabbage & 3 & 11 & 5 & 20 & 39 & 300 & 11.7 \\
\hline Broccoli & 2 & 12 & 8 & 25 & 47 & 300 & 14.1 \\
\hline Artichoke & 1 & 2 & 3 & 0 & 6 & 240 & 1.44 \\
\hline Green bean & 14 & 28 & 12 & 28 & 82 & 80 & 6.56 \\
\hline Strawberry & 32 & 9 & 0 & 1 & 42 & 170 & 7.14 \\
\hline Other flowers & 3 & 0 & 5 & 0 & 8 & 300 & 2.4 \\
\hline Other vegetables & 7 & 49 & 16 & 55 & 127 & 225 & 28.57 \\
\hline Total & 91 & 230 & 152 & 323 & 796 & 3255 & 153 \\
\hline
\end{tabular}

${ }^{1}$ Data supplied by correspondent Municipal Delegations.

${ }^{2}$ De Miguel and Payer (2002).

Induced recharge to the aquifer is estimated on the order of $0.99 \mathrm{Mm}^{3} /$ year $(20 \%$ of the circulating flow through the water supply network, approximately $4.93 \mathrm{Mm}^{3} /$ year). Thus, $9.8 \mathrm{t}$ of $\mathrm{NO}_{3}^{-}$-year reach the aquifer derived from the water supply leakage. The remaining $3.95 \mathrm{Mm}^{3} /$ year that supply urban areas return as untreated waste water through the sewage system. Common concentration for untreated urban waste water in the area of the Maresme is around $70 \mathrm{mg} / \mathrm{N} \mathrm{NO}_{3}^{-}$(Guimerà, 1992, 2004 -oral communication, Barcelona, Spain-). Considering that leakage in the sewage system is approximately $15 \%$ (data provided by the Municipal Delegations), an equivalent volume of 0.53 $\mathrm{Mm}^{3} /$ year returns to the aquifer. Such volume represents $42 \mathrm{t}$ of $\mathrm{NO}_{3}^{-}$-year based on the above mentioned nitrate concentration for waste water. Both leaks in the potable water supply and sewage networks account for a grand total of $51.8 \mathrm{t}$ of $\mathrm{NO}_{3}^{-}$-year.

The least important nitrate input into the aquifer is the incorporation of this ion by rainfall infiltration. According to climate records of the region and soil conditions, the mean annual recharge from rainfall infiltration was determined to be $1.20 \mathrm{Mm}^{3} /$ year over the full area of $8.2 \mathrm{~km}^{2}$ considered for the groundwater balance. Guimerà (1992) obtained results showing concentrations of $1 \mathrm{mg} \mathrm{NO}_{3}^{-/ 1}$ in the local rainwater; using this concentration, a total of 1.20 tons of $\mathrm{NO}_{3}^{-}$-year were calculated.

\subsubsection{Outputs}

Nitrate uptake from crops was estimated with assumptions developed by Custodio (1982) and applied by Guimerà and Candela (1989). In order to estimate the percentage of $\mathrm{N}$ lost by leaching, this methodology compares the ionic ratio $\mathrm{rSO}_{4}^{-2} / \mathrm{rNO}_{3}^{-}$of the applied fertilizer (R1) and groundwater composition (R2), considering that the main source of both sulfate and nitrate ions is the fertilizer application. Sulfate is not retained by the soil and is lost through leaching. Therefore, $\mathrm{R} 1 / \mathrm{R} 2$ ratio indicates the percentage of leached $\mathrm{N}$, while $1-(\mathrm{R} 1 / \mathrm{R} 2)$ is the percentage retained or used by crops. According to the composition of the most widely used fertilizers in the region, the incorporation of $\mathrm{NO}_{3}^{-}$to crops is represented by $\mathrm{R} 1=0.37$ (Custodio, 1982, Guimerà and Candela, 1989). In turn, R2 was obtained directly from the ionic relation $\mathrm{rSO}_{4}^{-2} / \mathrm{rNO}_{3}^{-}$, using the mean concentrations of sampled groundwater. This results in a R2 value of 1.72. This means that out of the total 677 tons of $\mathrm{NO}_{3}^{-} /$year entering the aquifer by fertilizers application, $79 \%$ (537 tons of $\mathrm{NO}_{3}^{-}$-year) is retained by the crops, and $21 \%$ of $\mathrm{N}$ is lost through leaching. This $21 \%$ represents the excess of fertilizer applied in the studied agricultural zone.

Nitrate ion extraction due to groundwater pumping was considered as another output term. According to the results of the hydrogeological balance performed in this research, the annual average of groundwater extraction amounts to $2.23 \mathrm{Mm}^{3} /$ year. Based on the mean $\mathrm{NO}_{3}{ }^{-}$concentration obtained from the groundwater sampling, a nitrate output of 307 tons $\mathrm{NO}_{3}{ }^{-}$-year was calculated.

Finally, attenuation was considered negligible due to the oxidizing nature of the environment (Guimerà, 1998; Vitòria et al., 2003). Adsorption was also considered negligible for practical purposes.

\subsubsection{Nitrate storage}

Based on equation (4) the aquifer received about 935.28 tons $\mathrm{NO}_{3}{ }^{-}$-year and yielded 844 tons of $\mathrm{NO}_{3}$ /year during the period under consideration. Therefore, the nitrate storage increase in the aquifer is in the order of $\Delta \mathrm{NO}_{3}{ }^{-}=+91.28$ tons $\mathrm{NO}_{3}{ }^{-}$year. 


\section{Conclusions}

Nitrate contamination was characterized for the North Maresme aquifer (Barcelona, Spain) through a mass-balance assessment of both hydrogeological and hydrogeochemical conditions of the system. Those wells with reliable piezometric records since 1990 show a slight and gradual rise of the water table of around $0.5 \mathrm{~m}$ for the coastal strip and the transition zone that is consistent with positive regional storage variation.

Hydrogeochemical facies vary in composition from $\mathrm{Ca}^{2+}-\mathrm{HCO}_{3}{ }^{-}$to $\mathrm{Ca}^{2+}-\mathrm{NO}_{3}{ }^{-}-\mathrm{SO}_{4}^{-2}-\mathrm{Ca}$ from recharge zone to the coastal strip. This indicates a gradual degradation of groundwater quality and can be explained by the inclusion of $\mathrm{N}$ compounds to the saturated zone through an indiscriminate application of fertilizers in agricultural fields.

The main analysis tool used in this research was a nitrate balance. This is an integrative approach to assess nitrate loading by linking different sources of nitrates to a groundwater balance. This methodology considers nitrate as a conservative ion, since the geological-geochemical medium behaves under oxidant conditions. Results show that the Maresme aquifer system receives, yields and retains approximately 935,844 and 91 tons of $\mathrm{NO}_{3}^{-}$/year, respectively.

This methodology can be applied to other nitratecontaminated aquifers with similar conditions, to improve management of fertilizers practices in agricultural areas.

This paper contributes to mass balance approach methodologies, as there is a great need to perform this kind of studies of agro-ecosystems at various scales to better understand the role of ground water as a reservoir and/or sink for $\mathrm{N}$ in the environment. Finally authors recommend integrating the proposed methodology with other $\mathrm{N}$ mass balance approaches, and furthermore, with $\mathrm{N}$ fate and transport modeling (Nolan et al., 2010) in order to improve management of fertilizers practices in agricultural areas.

\section{Acknowledgments}

The authors thank Dr. Jordi Guimerà and the thoughtful comments of the Counselors Committee of the Curso Internacional de Hidrología Subterránea (International Groundwater Hydrology Course, 38 CIHS) from the Polytechnic University of Catalonia. We also express our gratitude to the Catalonian Water Agency (ACA) for their involvement in carrying out hydrochemical analyses.

\section{References}

Almasri, M.N., 2007, Nitrate contamination of groundwater: A conceptual management framework: Environmental Impact Assessment Review, 27, 220-242.

Barry, D.A.J., Goorahoo, D., Goss, M.J., 1993, Estimation of nitrate concentrations in groundwater using a whole farm nitrogen budget:
Journal of Environmental Quality, 22, 767-775.

Bundy, L.G., Knobeloch, L., Webendorfer, B., Jackson, G.W., Shaw, B.H., 1994, Nitrate in Winconsin groundwater: sources and concerns: Madison, USA, U.S. Department of Agriculture, University of Wisconsin-Extension, cooperative Extension, Extension Publications G3054, 1-8.

Carey, B., Harrison, J., Van Wieringen, L., 2009, Groundwater Nitrate below a manured dairy field over the Sumas-Blaine aquifer: Washington D.C., State of Washington Department of Ecology, Publications, poster 09-03-027.

Chesnaux, R., Allen, D.M., 2008, Simulating nitrate leaching profiles in a highly permeable vadose zone: Environmental Modeling \& Assessment, 13, 527-539.

Crawford, N.M., 1995, Nitrate: nutrient and signal for plant growth: Plant Cell, 7, 859-868.

Custodio, E., 1982, Nitrate build-up in Catalonia coastal aquifers: International Association of Hydrogeologists Memoirs, 16, 171-181.

Custodio, E., Llamas, R., 1983, Hidrología Subterránea: Barcelona, Omega,Barcelona, 2 tomos 2359 p.

Da Costa, R., García, E., 1990, Actualización de los datos hidrológicos en la zona del Maresme Norte: Barcelona, Polytechnic University of Catalonia, Curso Internacional de Hidrologia Subterrránea, 24 CIHS.

Darcy, H., 1856, Les Fontaines publiques de la ville de Dijon: Exposition et application des principes a suivre et des formules a employer dans les questions de distribution d'eau... : Dalmont, París, Saraswati Press, 668 p.

Darnault, C., Rockne, K., Stevens, A., Mansoori, G.A., Sturchio, N., 2005, Fate of Environmental Pollutants: Water Environment Research, 77, 2576-2658.

De Miguel, A., Payer, L., 2002, Actualización de la contaminación del acuífero del Alto Maresme: Barcelona, Polytechnic University of Catalonia, Curso Internacional de Hidrología Subterránea, 36 CIHS.

Foppen, J.W.A., 2002, Impact of high-strength wastewater infiltration on groundwater quality and drinking water supply: the case of Sana'a, Yemen: Journal of Hydrology, 263, 198-216.

Gates, J.B., Böhlke, J.K., Edmunds, W.M., 2008, Ecohydrological factors affecting nitrate concentrations in a phreatic desert aquifer in northwestern China: Environmental Science \& Technology, 42, 3531-3537.

Guimerà, J., 1992, Análisis experimental de los procesos de flujo y comportamiento del ion nitrato en la zona no saturada y su influencia en el agua subterránea: Spain, Barcelona, Spain, Universitat Politecnica de Catalunya, PhD thesis, $186 \mathrm{p}$.

Guimerà, J., 1998, Anomalously high nitrate concentration in groundwater: Groundwater, 36, 495-512.

Guimerà, J., Candela, L., 1989, Contamination of The Maresme aquifer by agricultural practices, in Lobo-Ferreira J.P. (ed.), Proccedings of SISSIPA'89 Vol. III: Lisbon, Portugal, University of Lisbon, 61-71.

Guimerà, J., Marfà, O., Candela, L., Serrano, L., 1995, Nitrate leaching and strawberry production under drip irrigation management: Agriculture, Ecosystems \& Environment 56, 121-135.

Herbei, M.J., Spalding, R.F., 1993, Vadose zone fertilizer-derived nitrate and d15N extracts: Groundwater, 31, 376-382.

Joekar-Niasar, V., Ataie-Ashtiani, B., 2009, Assessment of nitrate contamination in unsaturated zone of urban areas: The case study of Tehran, Iran: Environmental Geology, 57, 1785-1798.

Ju, X.T., Kou, C.L., Zhang, F.S., Christie, P., 2006, Nitrogen balance and groundwater nitrate contamination: comparison among three intensive cropping systems on the North China Plain: Environmental Pollution, 143, 117-125.

Kim, D.Y., Burger, J.A., 1997, Nitrogen transformations and soil processes in a wastewater-irrigated, mature Appalachian hardwood forest: Forest Ecology and Management, 90, 1-11.

Kolpin, D.W., 1997, Agricultural chemicals in groundwater of the midwestern United States: Relations to land use: Journal of Environmental Quality, 26, 1025-1037.

Laegreid, M., Bøckman, O.C., Kaarstad, O., 1999, Agriculture, Fertilizers and the Environment: Porsgrunn, Norway, CABI Publishing in association with Norsk Hydro ASA, 294 p. 
Martínez-Beltrán, J., 1993, El regadío y las aguas subterráneas, in Pernia-Llera, J.M., Cuesta-Peiro, F., Ballesteros-Navarro, B., Barbara-Romero Muñoz, J., García-Sánchez, E. (eds.), Las aguas subterráneas: importancia y perspectivas: Madrid, Instituto Tecnológico GeoMinero de España, 29-48.

Nolan, B.T., Puckett, L.J., Ma, L., Green, C.T., Bayless, R., Malone, R.W., 2010, Predicting unsaturated zone nitrogen mass balances in agricultural settings of the United States: Journal of Environmental Quality, 39, 1051-1065.

Oakes, D.B., Young, C.P., 1981, The effects of farming practices on groundwater quality in the United Kingdom: Science of the Total Environment, 21, 17-30.

Pang, X.P., Letey, J., 2000, Organic farming: challenge of timing nitrogen availability to crop nitrogen requirements: Soil Science Society of America Journal, 64, 247-253.

Penuelas J, Sardans J, Alcaniz J.M., Poch J.M., 2009, Increased eutrophication and nutrient imbalances in the agricultural soil of $\mathrm{NE}$ Catalonia, Spain: Journal of Environmental Biology, 30, 841-846.

Piper, A.M., 1944, A graphic procedure in the geochemical interpretation of water analyses: American Geophysical Union Transactions, 25, 914-943.

Puckett, L.J., Cowdery, T.K., Lorenz, D.L., Stoner, J.D., 1999, Estimation of Nitrate Contamination of an Agro-Ecosystem Outwash Aquifer Using a Nitrogen Mass-Balance Budget: Journal of Environmental Quality, 28, 2015-2025.

Ryan, P.J., 1994, An evaluation of the state of nitrate/nitrogen contamination of the Abbotsford-Sumas Aquifer: British Columbia, Vancouver, Canada, University of British Columbia, MSc thesis, $203 \mathrm{p}$.

Sanchez-Perez, J.M., Tremolieres, M., Takatert, N., Ackerer, P., Eichhorn, A., Maire, G., 1999, Quantification of nitrate removal by a flooded alluvial zone in the Ill floodplain (Eastern France): Hydrobiologia, 410, 185-193.

Singleton, M.J., Esser, B.K., Moran, J.E., Hudson, G.B., McNab, W.W., Harter, T., 2007, Saturated Zone Denitrification: Potential for Natural Attenuation of Nitrate Contamination in Shallow Groundwater under Dairy Operations: Environmental Science \& Technology, 41, 759-765.

Stiff, H.A., 1951, The interpretation of Chemical analysis by means of patterns: Journal of Petroleum Technology, 3, 1, 15-116.
Suchanek, T.H., Cooke, J., Keller, K., Jorgensen, S., Richerson, P.J., Eagles-Smith, C.A., Harner, E.J., Adam, D.P., 2010, A mass balance mercury budget for a mine-dominated lake: Clear Lake, California: Water, Air, \& Soil Pollution, 196, 51-73.

Thornthwaite, C.W., 1948, An approach toward a rational classification of climate: Geographical Review, 38, 55-94

Torr, L.C., 2009, Applications of dairy wastewater as a fetilizer to agricultural land; an environmental management perspective: Stellenbosch, South Africa, University of Stellenbosch Departament of Geology, Geography and Environmental Studies, MSc thesis, $133 \mathrm{p}$.

Villabona, L. Jiménez, J., 1998, Estudio hidrogeológico del acuífero de Maresme, sector Calella-Malgrat: Barcelona, Polytechnic University of Catalonia, Curso Internacional de Hidrologia Subterrránea, 32 CIHS $122 \mathrm{p}$.

Villarroya, M., 1986, Estudio hidrogeológico del acuífero costero del Maresme Sur: Barcelona, Spain, Universidad de Barcelona, PhD thesis, $47 \mathrm{p}$.

Vitòria, L., Soler, A., Canals, A., 2003, Uso de isótopos ambientales (N, S, $\mathrm{C}, \mathrm{O}$ ) en la valoración de procesos de remediación natural de aguas contaminadas por nitratos: Barcelona, Spain, Memoirs, El agua y la ciudad sostenible: Hidrogeología Urbana, 23, 29.

Voudouris, K., Panagopoulos, A., Koumantakis, I., 2004, Nitrate Pollution in the Coastal Aquifer System of the Korinthos Prefecture (Greece): Global Nest: the International Journal, 6, 31-38.

Manuscript received: March 16, 2012

Corrected manuscript received: May 15, 2012

Manuscript accepted: June 15, 2012. 